\title{
Karpal Tünel Sendromu ve Ortalama Trombosit Hacmi Arasındaki İlişki
}

\author{
The Relation Between Mean Platelet Volume and Carpal Tunnel Syndrome \\ Fatih DOGAR ${ }^{1}$, Kaan GURBUZ ${ }^{2}$
}

\begin{abstract}
${ }^{1}$ Kahramanmaras Sutcu Imam University School of Medicine, Departments Orthopedics and Traumatology, Kahramanmaras, Turkey. ${ }^{2}$ Kayseri City Hospital, Departments of Orthopedics and Traumatology, Kayseri, Turkey.
\end{abstract}

\section{Özet}

Amaç: Bu çalışmanın amacı, Karpal Tünel Sendromu (KTS) ile anjiyogenez, tromboz, immünite ve inflamasyonla sonuçlanan ortalama trombosit hacmi (MPV) arasındaki ilişkiyi değerlendirmektir

Gereç ve Yöntemler: 2013 ve 2019 yılları arasında, 1660 hastaya mini-açık dekompresyon uygulandı ve sırasıyla 1056 sağlıklı birey kontrol grubu olarak retrospektif çalışmaya dahil edildi. Dışlama kriterleri sağlandıktan sonra 166 KTS hastası (141 kadın, 25 erkek) ve 156 kontrol hastası (80 kadın, 76 erkek) olarak iki grup belirlendi. KTS ve kontrol gruplarında, 12 saat aç kalındıktan sonar alınan venöz kan örneklerinden ortalama trombosit hacmi (MPV), trombositsayısı (PLT), trombosit dağılım genişliği (PDW), beyaz kan hücre (WBC) sayısı, hemoglobin (Hb), ESR ve CRP düzeyleri elde edildi ve hastane veri tabanında geriye dönük olarak kaydedildi. Ayrıca KTS grubundaki hastalardan postoperatif 6 . ve 12. ay kontrollerinde kan örnekleri alınarak operasyon öncesi çalışılan değerler dosyadan tekrardan kaydedildi.

Bulgular: KTS hastaları arasında, ameliyat sonrası 6 ayda ortalama MPV'de bazal değere kıyasla anlamlı bir fark vardı (p = 0,027). Ortalama MPV'de 1. yılda bazal değere göre anlamlı bir fark bulunmadı $(p=0,70)$. Ek olarak, KTS' li hastalar ve kontrol grubundaki hastalar arasında MPV değerlerinde veya diğer kan parametrelerinde (trombosit sayısı, beyaz kan sayımı, trombosit dağılımı genişliği ve hemoglobin) anlamlı bir fark bulunmadı.

Sonuç: Çalışmamızda KTS ile MPV arasında önemli bir ilişki bulunmadığını tespit ettik. Bu konuyu aydınlatmak için daha büyük örneklem büyüklüğüne ve geniş prospektif çalıșmaların gerekli olduğuna inanıyoruz.

Anahtar Kelimeler: Karpal Tünel Sendromu, Ortalama Trombosit Hacmi, Trombosit, İlișki

\section{Abstract}

Objective: The aim of this study was to evaluate the relationship between Carpal tunnel syndrome (CTS) and mean platelet volume (MPV) in which is related with angiogenesis, thrombosis, immunity and inflammation.

Material and Methods: Between 2013 and 2019, 1660 patients underwent mini-open decompression and 1056 healthy individuals were included in the retrospective study as study and control grup respectively. After the exclusion criteria are provide, patients were determined $166 \mathrm{CTS}$ patients and 156 control patients in two groups. In the CTS and control groups, mean platelet volume (MPV), platelet count (PLT), platelet distribution width (PDW), white blood cell(WBC) count, haemoglobin (Hb), ESR and CRP levels were obtained from venous blood samples drawn after 12-h fasting and were recorded retrospectively from the hospital database.In addition, blood samples were taken from the patients in the CTS group at the postoperative 6th and 12th month controls and the values studied before the operation were re-recorded from the file.

Results: Among the CTS patients, only there was a significant difference in the mean MPV at 6 months postoperatively compared to baseline (p=0.027). No significant difference was detected inthe mean MPV at 1 year compared to baseline $(\mathrm{p}=0.70)$. In addition, no significant differences were found in MPV values or in other blood parameters (platelet count, white blood count, platelet distribution width and haemoglobin) between patients with CTS and controls. Conclusion: We found that no significant relationship was detected between CTS and MPV in our study. We believe that further prospective studies with larger sample size are needed to elucidate this topic.

Keywords: Carpal Tunnel Syndrome, Mean Platelet Volume, Platelet, Relation.

Yazışma Adresi: Fatih DOĞAR, Kahramanmaras Sütçü İmam Üniversitesi Tıp Fakültesi Ortopedi ve Travmatoloji ABD, Kahramanmaraş, Türkiye Telefon: +90-530-4045489, Mail: drfatihdogar@hotmail.com

ORCID No (Sirasıyla): 0000-0003-3848-1017, 0000-0002-0144-5517

Geliş tarihi: 14.10.2020

Kabul tarihi: 12.11.2020

DOI: $10.17517 /$ ksutfd. 810636 


\section{INTRODUCTION}

Carpal tunnel syndrome (CTS) is one of the most frequently seen entrapment neuropathies (1). The syndrome generally occurs bilaterally and is more prominent in the dominant hand in $76 \%$ to $87 \%$ of the cases (2). It is more common in women and its incidence increases with advancing age. CTS is characterized by clinical symptoms, such as pain, paresthesia, hand dysfunction, muscular atrophy and weakness (1-3). Surgery is indicated in one-third of patients (1-3). The etiologyof CTS is multifactorial, with the most relevant risk factors being female gender, pregnancy, obesity, greater body mass index, age $>30$ years, fractures involving the wrist,systemic diseases, such as diabetes mellitus, rheumatoid arthritis and hypothyroidism and repetitive use of the dominant hand (3).

Platelets play a role in angiogenesis, thrombosis, immunity and inflammation $(4,5)$. The mean platelet volume (MPV) is a marker of platelet function and activation, and is low during active disease periods in patients with rheumatoid arthritis and ankylosing spondylitis (4-6). In addition, MPV is significantly higher in patients with psoriasis than in controls (7). In another study, MPV was significantly lower in osteoarthritis patients with active synovitisthan in controls (8).

Although many studies have reported that MPV is predictive in several chronic inflammatory disorders, to our knowledge there is none that shows the relationship between MPV and CTS in a controlled study.In this study, we hypothesized that there is a relationship between CTS, which has been classified as a chronic inflammatory disorder. Thus, MPV values were compared pre and postoperativelyin patients with CTS and between patients with CTS and healthy controls.

\section{MATERIAL and METHODS}

Among 3528 patients with CTS who underwent open decompression surgery at our two clinics (Kayseri City Training and Research Hospital and Kahramanmaras Sutcu Imam University Faculty of Medicine) between January 2013 and December 2019, 1660 were included in the retrospective study. In addition, 1060 healthy individuals served as controls.Patients with myeloproliferative disorders, immune thrombocytopenia, disseminated intravascular coagulation, and thrombotic thrombocytopenic purpura, which can alter the MPV value, and those who underwent bilateral surgery for CTS were excluded, as were patients with a previous history of acute myocardial infarction, elevated erythrocyte sedimentation rate (ESR) and C-reactive protein (CRP), previous bypass surgery and/or angiography, rheumatoid disease, renal disease, antithrombotic drug use, diabetes mellitus and a history of chronic disease.

In the CTS and control groups, MPV, platelet count (PLT), platelet distribution width (PDW), white blood cell(WBC) count, haemoglobin $(\mathrm{Hb}), \mathrm{ESR}$ and CRP levels were obtained from venous blood samples drawn after 12-h fasting and were recorded retrospectively from the hospital database.In addition, blood samples were taken from the patients in the CTS group at the postoperative 6th and 12th month controls and the values studied before the operation were recorded from the file. The patients with a WBC $>103 / \mu \mathrm{L}, \mathrm{ESR}>20 \mathrm{~mm} / \mathrm{s}$ and $\mathrm{CRP}>0.5 \mathrm{mg} / \mathrm{dL}$ were excluded. In this study conducted in two centers, the operations were performed by two surgeons and blood samples were studied in biochemistry laboratories in two centers.

CTS was diagnosed using a 4-channel electroneuromyography device when the peak sensorial conduction velocity of the median nerve was slower than $44 \mathrm{~m} / \mathrm{s}$ recorded in the second finger and/or the distal motor latency was longer than 3.6 $\mathrm{m} / \mathrm{s}$ recorded at the abductor pollicisbrevismuscle after stimulation of the median nerve at the $5 \mathrm{~cm}^{2}$ wrist segment.

The study protocol was approved by the Ethics Committee of Kahramanmaras Sutcu Imam University Faculty of Medicine(Decided no: 07, approval date 30.09.2020, session: 2020/18). All patients provided informed consent prior to study entry, and the study was conducted in accordance with the principles of the Declaration of Helsinki.

\section{Statistical Analysis}

Statistical analysis was performed using SPSS 22.0 programe (IBM SPSS for Windows version 22, IBM Corparation, Armonk, New York, United States). Frequency analysis was performed for categorical variables.The data was expressed in numbers and percentages. Whether acceptable variables fit the normal distribution, Single Sample was determined by Kolmogorov Smirnov test, Paired Student's t-test in non-parametric parameter analysis and Pearson chi-square test were used to compare categorical data groups. Ap value of $<0.05$ was considered statistically significant.

\section{RESULTS}

There were 141 women and 25 men in the CTS group, and 80 women and 76 men in the control group. There was no significant difference between the groups regarding sex $(p=0.274)$. The mean age was 55.2 years in the CTS group and 54.6 years in the control group $(p=0.340)$. Among the patients with CTS, the only significant difference was found between mean MPV values obtained at baseline (9.02) compared to those at 6 months postoperatively $(9.36, p=0.027$, see Table 1).

There was no significant difference between baseline and 1 -year postoperative MPV values $(8.97, p=0.700)$. When other blood parameters obtained at baseline were compared to those obtained at 6 months and 1 year postoperatively, no significant differences were found in mean PLT count (baseline, 290.04 compared to 6 months, 288.10 and 1 year, $297.83 ; p=0.780$ and $p=0.290$, respectively), mean PDW (baseline, 19.21 compared to 6 months, 19.71 and 1 year, 18.42; $p=0.340$ and $p=0.060$, respectively), mean WBC (baseline, 7895.51 compared to 6 months, 7661.26 and 1 year, 
Table 1. The comparison of laboratory findings of the CTS and control groups.

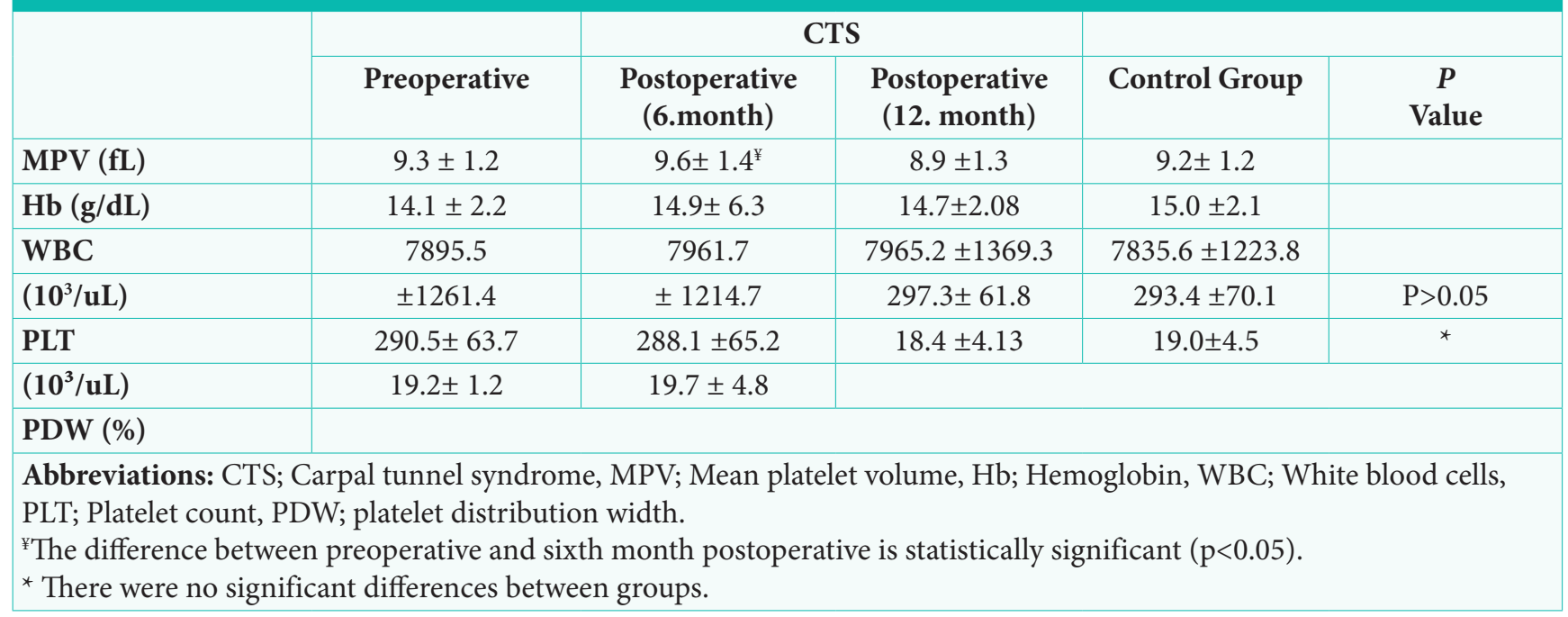

7965.72; $p=0.630$ and $p=0.580$, respectively) and mean $\mathrm{Hb}$ (baseline, 14.16 compared to 6 months, 14.99 and 1 year, 14.96; $p=0.105$ and $p=0.150$, respectively).

In the control group, mean MPV was 9.21, mean platelet count was 293.47, mean PDW was 19.39, mean WBC was 7835.26 and mean $\mathrm{Hb}$ was 15.07.No significant difference was detected in mean MPV value $(p=0.560)$, mean PLT count $(p=0.410)$, mean PDW $(\mathrm{p}=0.220)$, mean WBC $(p=0.770)$ and mean $\mathrm{Hb}(p=0.940)$ at baseline in the CTS group compared to those in the controls.

\section{DISCUSSION}

We hypothesized that there is a relationship between CTS, which has been classified as a chronic inflammatory disorder. Thus, MPV values were compared pre and postoperatively in patients with CTS and between patients with CTS and healthy controls. In addition, we believe that our study contributed to the understanding of CTS and helped clarify the relationship between MPV and CTS.

MPV demonstrates platelet function and activation (9). When platelets, which have a main role in haemostasis, are activated, inflammatory pathways are promoted by growth factors, cytokines and other bioactive substances that are released. MPV has been shown to be predictive in many chronic inflammatory diseases, ranging from stroke to osteoarthritis (10-13).

Previous studies have shown that PLT decreases in cases when MPV is increased. This finding is attributed to increased production of platelets with enhanced aggregation in bone marrow. However, elevated interleukin-6 levels (IL6) have been proposed to stimulate platelet production and lead to release of platelets with greater volume from bone marrow (13-15). It has been shown that platelets have a role in angiogenesis, thrombosis and immunity. The relationship ofplatelet value with inflammation was investigated in several studies, reporting that inflammation is an important stimulus for platelets (16). Proinflammatory cytokines, es- pecially IL-6, have a primary role in the pathogenesis of inflammatory arthritis $(6,14,15)$. Kisacik et al. (6) reported that a low MPV value was associated with inflammation in patients with rheumatoid arthritis and ankylosing spondylitis and increased with anti-inflammatory treatment. Osteoarthritis is a common disease that mainly involves joints, causing synovitis and tendinitis in the joints involved (17). In a study on osteoarthritis, MPV values were significantly lower in patients with knee osteoarthritis and active synovitisthan in those with osteoarthritis but without active synovitis (8). Canpolat et al. (18) found that the MPV was higher in psoriasis patients with arthritis than in those without arthritis and that there was a significant positive correlation between MPV and disease duration. Cardiovascular disease and carotid intima-media thickness are associated with CTS in those 60 years or older (19). Park et al. (20)found that carotid intima-media thickness was greater in patients with CTS than in controls; however, they suggested that an independent association exists between carotid intima-media thickness and CTS, which can be due to chronic inflammation.

Our study has several limitations. First, the study has a retrospective design. Second, sample size was small and may not reflect the general population. In some studies, the relationship between MPV, which is considered to be a simple, readily available inflammatory marker,and chronic inflammatory diseases has been investigated but no clear association could be established.

In conclusion, we found that no significant relationship was detected between CTS and MPV in our study. We believe that further prospective studies with larger sample size are needed to elucidate this topic.

\section{Conflict of Interest and Financial Status}

Our study has not been financed by an institution and institution. In this study, there is no conflict of interest among the authors on any subject

\section{Research Contribution Rate Statement Summary}

The authors declare that, they have contributed equally to the manuscript. 


\section{REFERENCES}

1. Werner RA, Andary M. Carpal tunnel syndrome: pathophysiology and clinical neurophysiology. Clin Neurophysiol. 2002;113(9):1373-1381.

2. Reinstein L. Hand dominance in carpal tunnel syndrome. Arch Phys Med Rehabil. 1981;62(5):202-203.

3. Becker J, Nora DB, Gomes I, Stringari FF, Seitensus R, Panosso JS, et al. An evaluation of gender, obesity, age and diabetesmellitus as risk factors for carpal tunnel syndrome. Clin Neurophysiol. 2002;113(9):1429-1434.

4. Bath P, Algert C, Chapman N, Neal B. Association of mean platelet volume with risk of stroke among 3134 individuals with history of cerebrovascular disease. Stroke 2004;35:622-626.

5. Wagner DD, Burger PC. Platelets in inflammation and thrombosis. Arterioscler Thromb Vasc Biol. 2003;23:2131-2137.

6. Kisacik B, Tufan A, Kalyoncu U, Karadag O, Akdogan A, Ozturk MA, et al. Mean platelet volume (MPV) as an inflammatory marker in ankylosing spondylitis and rheumatoid arthritis. Joint Bone Spine. 2008;75:291-294.

7. Karabudak O, Ulusoy RE, Erikci AA, Solmazgul E, Dogan B, Harmanyeri Y. Inflammation and hypercoagulablestate in adult psoriatic men. Acta Derm Venereol 2008;88:337-340.

8. Balbaloglu O, Korkmaz M, Yolcu S, Karaaslan F, Beceren NG. Evaluation of mean platelet volume (MPV) levels in patients with synovitis associated with knee osteoarthritis. Platelets. 2014;25:81-85.

9. Parh Y, Schoene N, Harris W. Mean platelet volume as a indicator of platelet activation: Methodological Issues. Platelets. 2002;13:301-306.

10. Foster TE, Puskas BL, Mandelbaum BR, Gerhardt MB, Rodeo SA. Platelet rich plasma: from basic science to clinical applications. Am J Sports Med.2009;37:2259-2272.
11. Nguyen RT, Bory-stein J, Mclinnis K. Applications of platelet rich plasma in musculoskeletal and sports medicine: an evidence based approach. PM\&R. 2011;3:226-250.

12. Down RB. The clinical and laboratuary utility of platelet volume parameters. Aust J Med Sci. 1994;15:12-15.

13. Bancroft AJ, Abel EW, Mclaren M, Belch JJ. Meant rombosit volume is a useful parameter: a reproducible routine method using a modified Coulter thrombocytometer. Platelets. 2000;11(7):379-387.

14. Gasparyan AY, Ayvazyan L, Mikhailidis DP, Gitas GD. Mean platelet volume: a link between trombosit and inflammation? Curr Pharm Des. 2011;17:47-58.

15. Kaser A, Brandacher G, Steurer W, Kaser S, Offner FA, Zoller $\mathrm{H}$, et al. Interleukin-6 stimulates thrombopoiesis through thrombopoietin: role in inflammatory thrombocytosis. Blood. 2001;98:2720-2755.

16. Smyth SS, McEver RP, Weyrich AS, Morrell CN, Hoffman MR, Arepally GM, et al. Platelet functions beyondhemostasis. J Thromb Haemost. 2009;7:1759-1766.

17. Pelletier JP, Martel-Pelletier J, Abramson SB. Osteoarthritis, an inflammatory disease: potential implication for the selection of new therapeutic targets. Arthritis Rheum. 2001;44:1237-1247.

18. Canpolat F, Akpinar H, Eskioglu F. Mean platelet volume in psoriasis and psoriatic arthritis. Clin Rheumatol. 2010;29:325-328.

19. Shiri R, Heliovaara M, Moilanen L, Viikari J, Liira H, Viikari-Juntura E.

Associations of cardiovascular risk factors, carotid intima-media thickness and manifest atherosclerotic vascular disease with carpal tunnel syndrome. BMC Musculoskelet Disord. 2011;12:80.

20. Park JH, Kim SN, Han SM, Cheon KY, Han SW, Kim JY, et al. Carotid intima-media thickness in patients with carpal tunnel syndrome. J Ultrasound Med. 2013;32:1753-1757. 